Original Research Article

\title{
Effect of ethyl acetate extract of Melothria perpusilla on intestinal absorption of glucose in albino rats
}

\author{
Shailendra Vikram Jitendra Singh*, Dharmaraja Meetei Usham, Subhalakshmi Devi Akham, \\ Rita Devi Sanjenbam
}

Department of Pharmacology, R.I.M.S, Imphal, Manipur, India

Received: 23 January 2017

Accepted: 03 February 2017

*Correspondence to:

Dr. Shailendra Vikram Jitendra

Singh,

Email:

shailendravikram121@gmail. com

Copyright: (C) the author(s), publisher and licensee Medip Academy. This is an openaccess article distributed under the terms of the Creative Commons Attribution NonCommercial License, which permits unrestricted noncommercial use, distribution, and reproduction in any medium, provided the original work is properly cited.

\begin{abstract}
Background: Diabetes mellitus is a spectrum of conditions that includes hyperglycemia. Safety issues limit the optimal use of anti diabetic drugs. The objectives of the study were to evaluate the effect of ethyl acetate extract of Melothria perpusilla (EAEMP) on intestinal absorption of glucose in albino rats.

Methods: Twenty four healthy albino rats were divided into four groups (control, standard, test I and test II) of six animals each weighing between 120$150 \mathrm{~g}$. Animals in control group were fed with $2 \%$ gum acacia, standard group with metformin $150 \mathrm{mg} / \mathrm{kg}$, test I with $250 \mathrm{mg} / \mathrm{kg}$ of EAEMP and test II with $500 \mathrm{mg} / \mathrm{kg}$ of EAEMP. After treatment for seven days, rats were fasted overnight. Intestinal loop of $10 \mathrm{~cm}$ from the pyloric end was prepared, keeping the blood supply intact under anaesthesia. One $\mathrm{ml}$ of $250 \mathrm{mg} \% \mathrm{D}$-glucose in normal saline was injected in the lumen of loop. Rats were sacrificed and the loop was removed after 15minutes. Weight of excised loop was measured and fluid was recovered. The glucose absorbed was calculated by the difference between the amount introduced and recovered after the absorptive period. After dehydrating, the dry weight of the tissue segment was measured. Intestinal glucose absorption was expressed in $\mathrm{mg} / \mathrm{g}$ dry weight tissue/h.

Results: The non parametric data were analysed by Kruskal Wallis test. Ethyl acetate extract of Melothria perpusilla produced a significant reduction in intestinal glucose absorption when compared with control and standard.

Conclusions: Treatment with Melothria perpusilla inhibits intestinal glucose absorption probably by inhibition of flavonoids on $\mathrm{Na}^{+}-\mathrm{K}^{+}$ATPase.
\end{abstract}

Keywords: Diabetes mellitus, Flavonoids, Melothria perpusilla, $\mathrm{Na}^{+}-$ $\mathrm{K}^{+}$ATPase

\section{INTRODUCTION}

Diabetes mellitus is a spectrum of common metabolic disorders caused by a variable combination of insulin deficiency and insulin resistance. Hyperglycemia is the most important and easily measured laboratory parameter liable for the pathological changes in almost every tissues of the human body. ${ }^{1}$ The resulting hyperglycemia produces various acute symptoms and metabolic abnormalities but chronic complications that arise from prolonged hyperglycemia are the major sources of morbidity in diabetes mellitus. ${ }^{2}$ Pharmacological studies related to the potential new anti-diabetic drug development is a continuous process and an area of interest among pharmacologists, physicians and endocrinologists. ${ }^{3}$ Issues of safety, tolerability and weight gain, often limit the optimal clinical application of anti- diabetic drugs such as sulfonylureas and thiazolidinediones. Moreover, the impact of different drugs, even within a single class, on the risk of long term vascular complications has come under scrutiny. ${ }^{4}$ Nature has created almost an inexhaustible array of molecular entities. It is as rich as an infinite resource for drug development, novel pharmacophores and scaffolds for amplification into efficacious drugs for a variety of disease indications and other valuable bioactive agents. Since remote past, natural products have been the spine of traditional system of healing throughout the world and have also been an integral part of history and culture. Although the use of bioactive natural products as herbal drug preparations dates back thousand of years ago, their application as isolated and characterized compounds to modern drug discovery and development started only in the 19 th century. ${ }^{5}$ Many plant extracts, which are tested 
for their suggested applications are available as prescription drugs in Europe. $^{6}$

Melothria perpusilla Cogn. is an endemic species found in the north eastern part of India, fairly common in the valley of Manipur. The plant is used traditionally by the people of Manipur for the treatment of jaundice and kidney problems other than kidney stones. Roots are used in fever and diarrhoea. Fruits have antihelminthic and demulcent action. ${ }^{7}$

Melothria perpusilla Cogn. (Family: Cucurbitaceae, Order: Cucurbitales), is a monoecious climber, the stem being deeply striate and glabrous. The fruits are smooth, globose and red when ripe, with many seeds which are flattened and smooth. The roots are oblong flattened tuber and are used with milk in fever and diarrhoea. The leaves and the fruit of Melothria perpusilla commonly known as creeping cucumber and popularly known as "Lamthabi" in Manipuri and Bankundri in Hindi have been used for diseases like jaundice and kidney disorders since ages. ${ }^{8}$ Two sterols and flavonol glycosides have been isolated from the chloroform extract of Melothria perpusilla Cogn. and are widely used in Manipur for the treatment of Jaundice. ${ }^{9,10}$ Unfortunately, significant data are not available in literature to substantiate the various traditional medical uses.

\section{METHODS}

\section{Approval}

Proper approval for the study was obtained from the "Institutional Animal Ethics Committee" (IAEC), Regional Institute of Medical Sciences (R.I.M.S.), Imphal, Manipur. Registration No. 1596/GO/a/12/CPCSEA.

\section{Set up}

The study was conducted in the Department of Pharmacology, R.I.M.S., Imphal, Manipur.

\section{Animals}

Twenty four healthy adult albino rats of either sex weighing between 120-150g were obtained from the central animal house, R.I.M.S., Imphal and divided into four groups of six animals in each group. The animals which were housed in the standard conditions of temperature, relative humidity $(55 \pm 5 \%)$, and light $(12 \mathrm{~h}$ light/dark cycles) were used. They were fed with standard pellet diet and water ad libitum.

\section{Collection of plants}

Melothria perpusilla plants were collected from the valley areas of Imphal West District, Manipur.

\section{Identification of plant}

The plant was identified and authenticated by Prof. H. Nandiram Sharma (retired) Professor of Botany, Manipur University.

\section{Preparation of test drug}

Melothria perpusilla plant was collected from the valley areas of Imphal West District, Manipur. The aerial portions of the plant were completely shade dried and then it was powdered which was subjected to defatting using petroleum ether (B.P. $\left.40^{\circ}-60^{\circ}\right) .^{11}$ The plant material was emptied and washed using $95 \%$ ethyl alcohol and adherent solvent was evaporated by spreading the plant materials which were later repacked with the dried plant material; thus, the test compound was obtained by using ethyl acetate solvent. ${ }^{12,13}$ The apparatus used in the extraction of the test drug was soxhlet apparatus. ${ }^{14}$ The yield at the end of extraction was $0.40 \%$.

\section{Preliminary photochemical screening}

When a few drops of lead acetate solution were added to a small quantity of the extract, a yellow coloured precipitate was formed. Also, when a few drops of sodium hydroxide was added to a small quantity of the extract, yellow coloured precipitate was formed which became colourless on addition of dilute acid. Both of these tests indicate the presence of flavonoids.

\section{Acute toxicity study}

Melothria perpusilla was used in the food ingredients since thousands of years. Therefore, we conducted the limit test of the test compound. Ethyl acetate extract of Melothria perpusilla (EAEMP) was administered in albino rats at one dose level of $2000 \mathrm{mg} / \mathrm{kg}$ per orally. There was no mortality at $2000 \mathrm{mg} / \mathrm{kg}$ per orally and two doses of $250 \mathrm{mg} / \mathrm{kg}$ and $500 \mathrm{mg} / \mathrm{kg}$ were chosen for the study. ${ }^{15}$

\section{Experimental study}

Table 1: Distribution of various groups.

\begin{tabular}{|ll|}
\hline $\begin{array}{l}\text { Animal } \\
\text { groups }\end{array}$ & Treatment \\
\hline Group 1 & $2 \%$ gum acacia suspension in distilled water \\
\hline Group 2 & EAEMP- $250 \mathrm{mg} / \mathrm{kg}$ p.o. in $2 \%$ gum acacia \\
\hline Group 3 & EAEMP- $500 \mathrm{mg} / \mathrm{kg}$ p.o. in $2 \%$ gum acacia \\
\hline Group 4 & Metformin $150 \mathrm{mg} / \mathrm{kg}$ p.o. in $2 \%$ gum acacia \\
\hline
\end{tabular}

The effect of ethyl acetate extract of Melothria perpusilla (EAEMP) on intestinal absorption of glucose was studied by the method adopted by Das $\mathrm{S}$ et al. ${ }^{16}$ Animals were divided into four groups of six animals in each group and were treated in the following ways (Table 1). 
The albino rats were treated by the above methods for a period of seven days. Following this, they were kept for overnight fasting. Proper care was taken to prevent coprophagy and to provide free access to water. Animals were anaesthetised with sodium pentothal ( $40 \mathrm{mg} / \mathrm{kg}$ i.p.). Through a midline abdominal incision in each albino rat, an intestinal loop of $10 \mathrm{~cm}$ in length from the pyloric end was prepared, keeping the blood supply intact. One $\mathrm{ml}$ of $250 \mathrm{mg} \%$ D-glucose in normal saline at $37^{\circ} \mathrm{C}$ was injected in the lumen of the loop with the tuberculin syringe. After an absorptive period of 15 minutes, each rat was sacrificed and the loop was removed. The weight of the excised loop was taken after stripping off the fat and mesentery, and the loop was cut open to recover the fluid left after the absorption. The glucose absorbed was calculated by the difference between the total amount introduced in the lumen and the amount recovered after the absorptive period. The dry weight of the tissue segment was measured after dehydrating it with $95 \%$ ethyl alcohol for a period of $24 \mathrm{~h}$, followed by drying for $2 \mathrm{~h}$ at $120^{\circ} \mathrm{C}$ in the hot air oven. The intestinal glucose absorption was expressed in $\mathrm{mg} / \mathrm{g}$ dry weight of the tissue/h.

\section{Glucose estimation}

Glucose was estimated by enzymatic colorimetric method using glucose kit (Avantor) as per the instructions mentioned in the kit manual provided by the manufacturer.

\section{Analysis of results}

The intestinal glucose absorption (mg/g dry wt/h) was expressed as Mean \pm Standard Deviation. The non parametric data were analysed by Kruskal Wallis test. $\mathrm{P}$ $<0.05$ was considered statistically significant.

\section{RESULTS}

Table 2: Effect of ethyl acetate extract of Melothria perpusilla (EAEMP) on intestinal glucose absorption.

\begin{tabular}{|c|c|c|}
\hline $\begin{array}{l}\text { Animal } \\
\text { groups }\end{array}$ & Treatment & $\begin{array}{l}\text { Glucose absorption } \\
\text { (mg/g of dry } \\
\text { weight tissue/h ) }\end{array}$ \\
\hline $\begin{array}{l}\text { Group I } \\
\text { (Control) }\end{array}$ & $\begin{array}{l}2 \% \text { gum acacia } \\
(1 \mathrm{ml} / 100 \mathrm{~g})\end{array}$ & $16.71 \pm 0.66^{\#}$ \\
\hline $\begin{array}{l}\text { Group II } \\
\text { (Test } \\
\text { drug) }\end{array}$ & $\begin{array}{l}\text { EAEMP } 250 \mathrm{mg} / \mathrm{kg} \text { in } \\
2 \% \text { gum acacia } \\
\text { suspension }\end{array}$ & $15.22 \pm 0.40^{* \#}$ \\
\hline $\begin{array}{l}\text { Group III } \\
\text { (Test } \\
\text { drug) }\end{array}$ & $\begin{array}{l}\text { EAEMP } 500 \mathrm{mg} / \mathrm{kg} \text { in } \\
2 \% \text { gum acacia } \\
\text { suspension }\end{array}$ & $14.06 \pm 0.38^{* \# .}$ \\
\hline $\begin{array}{l}\text { Group IV } \\
\text { (Standard) }\end{array}$ & $\begin{array}{l}\text { Metformin }(150 \\
\mathrm{mg} / \mathrm{kg} \text { p.o. })\end{array}$ & $13.36 \pm 0.21^{*}$ \\
\hline \multicolumn{3}{|c|}{$\begin{array}{l}\text { Values expressed as mean } \pm \text { standard deviation, } n=6 \text { in each } \\
\text { group. } \\
* \mathrm{p}<0.01 \text { when compared with control } \\
\# \mathrm{p}<0.01 \text { when compared with standard } \\
\text {. } \mathrm{p}<0.01 \text { when compared with test drug in group II }\end{array}$} \\
\hline
\end{tabular}

The intestinal glucose absorption $(\mathrm{mg} / \mathrm{g}$ dry $\mathrm{wt} / \mathrm{h})$ in the control, standard, EAEMP- $250 \mathrm{mg} / \mathrm{kg}$ and $500 \mathrm{mg} / \mathrm{kg}$ treated groups were $16.17 \pm 0.66,13.36 \pm 0.21,15.22 \pm 0.40$, $14.06 \pm 0.38$ respectively. Standard and EAEMP treated groups showed highly significant reduction in absorption when compared with the control. There was a highly significant difference between EAEMP treated groups with the standard treated groups. Also there was a highly significant difference among EAEMP treated groups of both the doses (Table 2).

\section{DISCUSSION}

Albino rats of the weight range (120-150g) were selected and used for the study purpose to minimize the differences in the intestinal absorption. Test drug was extracted with various solvents in Soxhlet apparatus using petroleum ether as defatting agent, ethanol for washing out the impurities and final extraction with ethyl acetate. ${ }^{11-13}$ The study was conducted on the intact intestinal loop after an overnight fasting for $18 \mathrm{~h}$. This time duration is sufficient to keep the proximal small intestine empty. ${ }^{17}$

Selection of the intestinal portion starting from the pyloric end is justified as proximal and mid small intestine has the maximum capacity to absorb the sugars. ${ }^{18}$ In our study model, the proximal $10 \mathrm{~cm}$ segment of small intestine from the pyloric end was selected to evaluate the intestinal glucose absorption with an absorptive period of 15 minutes. Metformin used as a standard drug, belongs to the biguanides and acts by various mechanisms like increasing the glucose uptake and helping in glucose utilisation by the skeletal muscles, inhibiting the hepatic gluconeogenesis and decreasing hepatic glucose output, slowing down the glucose absorption through the gut and promoting the binding of insulin to its receptor. ${ }^{19}$

The inhibitory effect of metformin on glucose absorption in the study supports the validity of the adopted study model. Ethyl acetate extract of Melothria perpusilla produces significant reduction of intestinal glucose absorption when compared with the control group and the small working test dose of $250 \mathrm{mg} / \mathrm{kg}$ EAEMP produces less inhibition of glucose absorption than $500 \mathrm{mg} / \mathrm{kg}$ EAEMP when compared with the standard.

Glucose has a dual step process involving its uptake from intestinal lumen across the apical membrane into epithelial cell and an exit across the basolateral membrane. The uptake at the apical membrane is carried out by a membrane protein called Sodium/Glucose cotransporter (SGLT1), whereas exit at the basolateral membrane is through a facilitated sugar transporter called glucose transporter 2 (GLUT2). The uptake at the apical membrane is an active process, where energy is supplied by electrochemical $\mathrm{Na}^{+}$gradient maintained by extrusion of $\mathrm{Na}^{+}$across the basolateral membrane by $\mathrm{Na}^{+}-\mathrm{K}^{+}$pump $\left(\mathrm{Na}^{+}-\mathrm{K}^{+}\right.$ATPase). The inhibition of membrane $\mathrm{Na}^{+}-\mathrm{K}^{+}$ 
pump decreases apical membrane $\mathrm{Na}^{+}$gradient resulting to a decline in the driving force for glucose entry into intestinal epithelium. ${ }^{20}$ The flavonoids are known to inhibit membrane $\mathrm{Na}^{+}-\mathrm{K}^{+}$ATPase. ${ }^{21}$ The presence of these chemicals in the extract (EAEMP) strongly suggests that it inhibits membrane $\mathrm{Na}^{+}-\mathrm{K}^{+}$ATPases, which provide the driving force for glucose entry into intestinal epithelium.

\section{CONCLUSION}

Thus, in this study, it has been found that Melothria perpusilla inhibits the intestinal absorption of glucose in a dose dependent manner and the effect may be attributed to flavonoids. Further studies will be helpful to evaluate its role in the treatment of hyperglycemia which may lead to the development of an efficient anti-diabetic drug.

\section{Funding: No funding sources}

Conflict of interest: None declared

Ethical approval: The study was approved by the Institutional Ethics Committee

\section{REFERENCES}

1. Satoskar RS, Rege NN, Bhandarkar SD. Pharmacology and Pharmacotherapeutics. 24 ${ }^{\text {th }}$ ed. Mumbai: Popular Prakashan Pvt. Ltd; 2015.

2. Powers AC, D'Alessio D. Endocrine Pancreas and Pharmacotherapy of Diabetes Mellitus and Hypoglycemia. In: Brunton LL, Chabner BA, Knollman BC, editors. The Pharmacological Basis of Therapeutics. $12^{\text {th }}$ ed. New York: The Mc Graw Hill Companies; 2011:1237-1273.

3. Rang HP, Ritter JM, Flower RJ, Henderson G. Pharmacology. 8th ed. New York: Churchill Livingstone; 2016:391.

4. Krentz AJ, Patel MB, Bailey CJ. New drugs for type 2 diabetes mellitus: What is their place in therapy? Drugs. 2008;68(15):2131-62.

5. Veeresham C. Natural products derived from plants as a source of drugs. J Adv Pharm Technol Res. 2012;3(4):200-1. Available from: http://www.ncbi.nlm.nih.gov/pmc / articles /PMC 3260124/. Accessed on Sep 22, 2016.

6. Subramoniam A, Pushpangadan P. Development of phytomedicines for liver diseases. Indian $\mathbf{J}$ Pharmacol. 1999;31:166-75.

7. Kiritikan KR, Basu BD. Melothria perpusilla Cogn. In: Blatter E, Caius JF, Mlaskar KS, editors. Indian Medicinal Plant. 2nd ed. Dehradun: International Book Distributors; 1987:161-162.
8. Leisangthem S, Sharma LD. Study of some important medicinal plants found in Imphal-East District, Manipur, India. Int J Scien Res Pub. 2014;4(9):3.

9. Sinha SC. Medicinal plants of Manipur, Imphal (Manipur): Manipur Association for Science and Society (MASS); 1996.

10. Langoljam RD, Kongbrailatpam BD, Loitongjam WS. Sterols and flavonol glycosides from Melothria perpusilla Cogn. Indian J Chem. 2005;44(B):1291-4.

11. Beckett AH, Stenlake JB. Solvent extraction methods practical pharmaceutical chemistry. $3^{\text {rd }}$ ed. London: The Anthlone Press; 1975.

12. Chattopadhyay RR, Sarkar SK, Ganguly S, Banerjee RN, Basu TK. Indian J Physiol Pharmacol. 1991;35(3):45-51.

13. Brahmachari HD, Augusti KT. Isolation of orally effective hypoglycaemic compounds from Ficus bengalensis Linn. Indian $\mathbf{J}$ Physiol Pharmacol. 1964;8:60-4.

14. Knevel AM, Digangi FE. Jenkin's Quantitative Pharmaceutical Chemistry. $7^{\text {th }}$ ed. New York: Mc Graw Hill Book Co; 1977.

15. OECD Test Guideline 423: Acute oral toxicity Acute toxic class method. Available from:http://iccvam.niehs.nih.gov/SuppDocs/FedDocs /OECD/OECD_GL423.pdf. Accessed on Dec 21, 2016.

16. Das S, Jadav RK, Nagchoudhuri J. Indian J Physiol Pharmacol. 2001;45(4):451-6.

17. RK Sharma. J Nagchoudhuri. Indian J Med Res. 1976;64(8):1225-34.

18. Henry HJ. Disorders of absorption. In: Kasper DL, Hauser SL, Jameson JL, Fauci AS, Longo DL, Loscalzo J, editors. Harrison's Principles of Internal Medicine. $19^{\text {th }}$ ed. New York: McGraw Hill; 1988:1932-1946.

19. Sharma HL, Sharma KK. Principles of Pharmacology. $2^{\text {nd }}$ ed. Hyderabad: Paras Medical Publishers; 2013.

20. Binder HJ. Reuben A. Nutrient digestion and absorption. In: WF Boron, EL Boulpaep, editors. Medical Physiology. Updated Edition. Philadelphia: Elsevier Saunders; 2005:947-974.

21. Middleton E, Kandaswami C, Theoharides TC. The effects of plant flavonoids on mammalian cells: implications for inflammation, heart disease, and cancer. Pharmacol Rev. 2000 Dec;52(4):673-751.

Cite this article as: Singh SVJ, Usham DM, Akham $\mathrm{SD}$, Sanjenbam RD. Effect of ethyl acetate extract of melothria perpusilla on intestinal absorption of glucose in albino rats. Int $\mathrm{J}$ Basic Clin Pharmacol 2017;6:543-6. 